each other, and hence much of the secondary layer is not resolvable into distinct fibres. At certain places, however, slight variations in the curves take place; they become opposed, and a small depression of the outer membrane results, or the few opposed curves may be large, and hence a greater hollow will ensue; but in these vessels very little matter is added to the internal layer, perhaps none, and hence no dot or canal is apparent in them (Pl. XII. fig. d.).

The spiral and sinuous direction of the fibres of the secondary layer is very easily recognizable, at least when punctated vessels are carefully examined; but the attention of the observer should be strongly directed to it, as the brighter appearance of the punctations themselves, from the light only passing through a less thickened layer of membrane, draws more powerful consideration to them. It may also be well observed when a vessel is cut, or when it breaks itself at the side (as at fig. $f$.).

The section of a completely formed punctation is seen at Pl. XII. fig. $g$; the dotted line indicates the primary membrane, the broader dark line beneath it the fibre.

It will be seen that we thus differ from Mohl in believing that a secondarily formed fibrous layer, consisting of filaments bent upon themselves, is mainly instrumental in the formation of punctations, and agree with him in the circumstance of the depression being caused by a sinking-in of the primary membrane, but which latter condition never could exist without the previous existence of the fibres alluded to. We also consider the fibres or filaments not to be of primary development, and not as serving in this particular as a support to Dr. Barry, in what we have thought to have been his views. (Figs. $a$. and $b$. are from Meyen.)

XLIX.-A Catalogue of Shells from the Crag. By S. V. Wood, Esq., F.G.S.

[With a Plate.]

[Continued from vol. vi. p. 253.]

To the Editors of the Annals of Natural History.

Gentlemen,

IT has been my object with the present as well as the preceding portion of this Catalogue to adhere as closely as possible to the classification of Lamarck; my only deviations from the system of that eminent naturalist are those rendered necessary by the additions that have been made to the science of Malacology, and the establishment of new genera by other writers. I have also myself thought it requisite to propose a few for 
some forms in my own cabinet. Mr. Lyell and Capt. Alexander have kindly furnished me with the list of shells from the mammaliferous crag*, while those from the red and coralline are what my own cabinet contains, every species of which I have myself collected.

With respect to the utility of this Catalogue as one means of arriving at the relative ages of the three deposits to which it has reference, it should be borne in mind that some amount of error may arise from the imperfect state or altered condition of many fossil species; some modifications in the several proportions of extinct to recent species may also arise from future researches both in recent and fossil conchology, a source of error mentioned by Mr. Charlesworth. And in applying the percentage test to these tertiary beds, allowance should be made for the absence from the red and mammaliferous crag of certain species found in the coralline and also inhabiting our own seas, amounting to nearly ten per cent., many of them minute and fragile. Mr. Lyell, in his paper upon the relative ages of the Crag of Norfolk and Suffolk, ' Mag. of Nat. Hist.,' 1839 , p.322, says, "If they" (the recent species just referred to) "should hereafter be detected in beds strictly contemporary with the red crag, it by no means follows that they would alter the proportion of thirty per cent., because with them we might expect to bring to light a great number of extinct species which would probably agree with the extinct species of the coralline crag, whilst others would be peculiar to the red crig." Now on this point I must beg to dissent from Mr. Lyell, as I consider a part, at least, of these recent species should be allowed for in our estimates, since we know they must have existed through the intermediate period; and though in our researches for these absent species we should in all probability bring to light a number of extinct forms, so at the same time we might expect to discover with them a number of forms identical with those now living in our own seas but not known in the coralline crag, and that we have as much reason to expect in our new discoveries that the extinct species should not much exceed the proportionate number of recent not found in the older bed, as that those absentees should be the only recent species that we may hereafter discover. We have not however yet arrived at that know-

* Dr. Buckland states in his Anniversary Address to the Geological Society for 1840 , p. 236 , that Mr. Lyell proposẽs the term "Norwich Crag" for the newest of the three crag deposits, but I have employed throughout this catalogue Mr. Charlesworth's name " Mammaliferous Crag," which he gave to this formation in the year 1836, and which has consequently the right of priority. (See Proc. of Brit. Assoc. for 1836.) 
ledge of the contents of these beds which would enable us to determine with precision the number of species each formation possesses. I give my Catalogue more to show the riches of our tertiary deposits than with the expectation that any generalizations can be established where so many sources of error are likely to interfere with our calculations, hoping that a better acquaintance with recent British Testacea will enable me at a future period to correct some of the errors it may probably be found to contain. Many of the identifications in this Catalogue have of necessity been based upon figures and descriptions, but a comparison with the specimens themselves is in all cases essential to correct determination.

With respect to the temperature of the sea during the formation of these deposits, various and conflicting opinions have been given. The coralline crag, it has been asserted, presents us with indications of a tropical nature; a conclusion which has been drawn from the profusion of Polyparia that this formation contains. In regard to the evidence given by the presence of Testacea, it has been imagined on the one hand, that such genera as Glycimeris, Trichotropis, Astarte and Cyprina, and the large development of these latter forms, give reason to conclude the climate was at least as cold as what we experience at the present day; but it may be remembered that Astarte and Cyprina are both found in the London clay associated with shells whose analogous forms are only now living in tropical climates, and that the Glycimeris has been found upon the coast of Massachusetts; on the other hand, the Pyrule are all denizens of the Oriental seas, and the only species of Pholadomya yet known was procured near one of the West India Islands ; these favour the assumption that the sea of the crag period was of a warmer temperature. Several of the species of the coralline crag have been found living in the Mediterranean, and as far as we know at present restricted to that part of the world. It is strange to find associated in the same formation such apparently incongruous types as Pyrula and Pholadomya, Glycimeris and Astarte, the one representing the tropical form, while the other is generally found in the North; but if we only give a little extension to the geographical range of each of these types, allowing what are generally considered to be northern genera to reach as far to the southward as we would give the same indulgence to those that appear exclusively of a tropical character, it would approximate the latitude and probably the temperature of that great inland sea or that of the coast of Portugal, to which I would assign the temperature of the Ann.\& Mag. N. Hist. Vol. ix. 
coralline crag. I would further remark in support of the above opinion, that there are in the coralline crag a few genera, which, if not possessing decidedly tropical characters, have not hitherto been found in the North, viz. Pholadomya, Chama and Lingula, Cancellaria, Cassidaria, Columbella ?, Terebra, Pleurotoma, Pyrula and Mitra.

I must again repeat, that the names for the new species are merely provisional, and the synonyma introduced are those only that I have considered requisite for the true understanding of the species.

Class ANNULATA.

Cor. Crag. Red Crag. Mam. Crag. Recent.

1. Spirorbis granulatus (Serpula granulata, Mont. Test. Brit. p. 500),

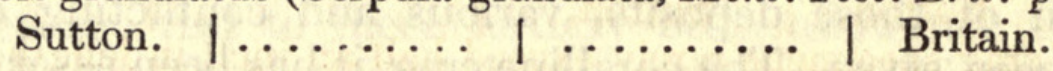

2. - heterostrophus (Serpula heterostropha, Mont.Test.Brit.p.503).

Sutton. | . . . . | . . . . . | Britain.

3. - carinatus (Serpula carinata, Mont. Test. Brit. p. 502).

Sutton. I Sutton. | $\ldots \ldots \ldots$ | | Britain.

4. - sinistrorsus (Serpula sinistrorsa, Mont. Test. Brit. p. 504).

Sutton. | Sutton. | $\ldots \ldots \ldots$ | Britain.

1. Vermilia triquetra (Serpula triquetra, Mont. Test. Brit. p. 511).

Sutton. I Sutton. | $\ldots \ldots \ldots \ldots$ | Britain.

2. - vermicularis (Serpula vermicularis, Mont. Test. Brit. p. 509).

Sutton. | Sutton. | $\ldots \ldots \ldots$ | Britain.

3. - supra-plana, n. s.

Sutton. I Sutton. I ।

4. - tricuspidata (Serpula tricuspidata, Sow. in Tankerville Catalogue,

1825, Appendix, p. 1. Serpula serrulata, Flem. Edinb. Ency. vii. p. 67. pl. 204. f. 8).

Sutton. $|\ldots \ldots \ldots| \ldots \ldots \ldots$ | Britain.

1. Filograna.

Sutton. | ....... | Bramerton. | Britain.

My specimens are all attached laterally the entire length.

1. Serpula? recta, Walker (Test. Min. rar. f. 11).

Sutton. | $\ldots \ldots \ldots \mid \ldots \ldots \ldots$ | Britain.

1. Cyclogyra multiplex.

Sutton.

I have given this a name provisionally, and placed it in its present position with considerable doubt. The volutions are numerous and completely discoidal, partly enveloping the preceding whorl; they are not tubular, neither do they possess the regularity of a convoluted mollusc. A similar shell has been figured by D'Orbigny as Operculina, but the removal of one side of several volutions shows the interior without partitions. Diameter $\frac{1}{7}$ th of an inch. Pl. V. f. 5. 


\section{Class PTEROPODA.}

\section{Ord. Thecosomata.}

Cor. Crag. Red Crag. Mam. Crag. Recent.

1. Cleodora infundibulum, n. s.

Sutton.

Spec. Char. Elongate, trumpet-shaped, smooth, bicarinate, open at both ends.

This shell is now opake, and has an opening at the smaller end, which may be perhaps accidental. Only four specimens. Length quarter of an inch; greatest diameter one-tenth. Pl. V. f. 13.

1. Ditrupa subulata, Berkeley (Zool. Journal, vol. v. p. 427. pl. 19.

f. 2. Dentalium subulatum, Deshayes, Monograph de Dent. pl. 2. f. 29).

\section{Sutton. I Sutton.}

The crag specimens rarely exceed half an inch in length.

2. - polita, n. s.

$$
\text { Sutton. }
$$

Shell slightly arcuated, thin, smooth, subcylindrical; anterior opening plain, posterior cleft, bilateral, with unequal terminations. Pl. V. f. 14.

The body of the crag shell is not inflated or enlarged like that of D. gadus, but has the posterior opening laterally cleft, somewhat resembling that of D. coarctata, Dentalium coarctatum, Deshayes, 'Monog. de Dent,' pl. 4. f. 18. (which is however distinct from ga$d u s$ ), but the dorsal part of the posterior end of this fossil is produced beyond the edge beneath and rounded, the ventral edge is shorter and truncated, an enamel-like polish covers the exterior, and was probably when inhabited subhyaline, but is now opake. Length half an inch nearly.

1. Cæcum trachea ? Flem. (Edinb. Encyclop. vol. vii. p. 67. Dentalium trachea, Mont. Test. Brit. p. 497, t. 14. f. 10 . Odontidium rugulosum? Phil. En. Moll. Sicilia, p. 102.t.6. f. 20).

Sutton. $|\ldots \ldots \ldots \ldots| \ldots \ldots \ldots \mid$ Britain.

The recent British shell is regularly annulated and smooth, the annuli in my single crag specimen are more irregular and rugose.

2. - mammillum, n. s.

Sutton. 1 ।

3. - glabrum ? (Dentalium glabrum, Mont. Test. Brit. p. 479).

Sutton. | ....... | ....... | Britain.

\section{Class GASTEROPODA.}

Ord. Gymnobranchiata.

Cor. Crag. Red Crag. Mam. Crag. Recent.

1. Chiton fascicularis, Sow., Jun. (Conch. Illust.Brit. Chitones, f.87a).

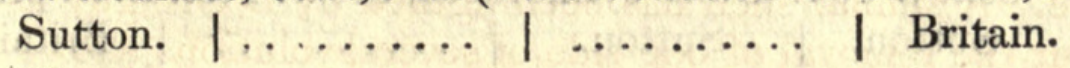

2. - strigillatus, $\mathrm{n}, \mathrm{s}$.

Sutton. 

Cor. Crag.
Red Crag.
Mam. Crag.
Recent.

3. Chiton tenui-sculptus, n. s. Sutton.

4. - arcuarius, n. s. Sutton.

5. - angulosus, n. s.

Sutton.

I have considered these as Nov. Spec. with doubt, having been unable to procure more than four British species to compare with, and all the hitherto published figures and descriptions are inadequate for that purpose. In order to obtain a correct determination in the fossil Chitons (where seldom more than detached valves are met with), their degree of convexity must be ascertained, their altitude and relative dimensions of length and breadth, the amount also of angularity in the central valves, and the shape and magnitude of the sustentacula, or processes at the posterior part of each, which vary in all the species I have examined.

1. Lottia virginea, Gray (var. a. Patella virginea, Müller, Z. D. Prod. 237. var. $\beta$. Patella conica, Jeffries. Patella equalis, Min. Con. t. 139).

Sutton. | Sutton. | $\ldots \ldots \ldots \mid$ Britain.

2. - ? parvula (Patella parvula, Woodward, Geol. of Norf. t. 3. f. 1).

1. Patella vulgata, Linn. | Bramerton. |

Sutton.

Britain.

Only one imperfect specimen; it differs from the common character of the recent shell in having the rays slightly imbricated.

\section{Ord. Pleurobranchiata.}

\section{Cor. Crag. RedCrag. Mam.Crag. Recent.}

1. Bulla catenata, mihi (Scaphander catenatus, Leach, Moll. p. 55. Bullæa angustata, Phil. Enum. Moll. Sic. p. 121. t. 7. f. 17. Bulla dilatata, Wood, Illust. Mag. Nat. Hist. pl. 7).

Sutton. | ....... |....... | Britain.

2. - quadrata, Wood (Illust.Mag.Nat.Hist. 1839, p. 460. pl.7. f. 1). Sutton. I

3. - sculpta, mihi (B. catenata,Wood,Illust.Mag.Nat.Hist.pl. 7.f.2). Sutton.

4. - lignaria, Auct. (Illust. pl. 7. f. 4).

Sutton. | Sutton. | ....... Britain.

5. - ventrosa, Wood (Illust. pl. 7. f. 5).

Sutton. i

6. - cylindracea, Wood (Illust. pl. 7. f. 8. Bulla convoluta, Min. Con. t. 464. Bulla cylindracea, Mont. Test. Brit. pl. 7. f. 2),

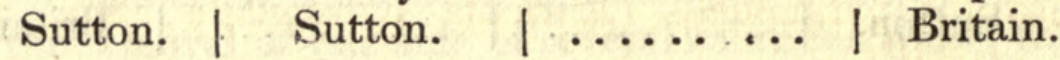

7. - truncata, Mont. (Bulla subtruncata, Wood, Illust. pl. 7. f. 9). Sutton. $|\ldots \ldots \ldots \ldots| \ldots \ldots \ldots \mid$ Britain. 
Cor.Crag. Red Crag. Mam.Crag. Recent.

8. Bulla Conulus, Desh. (Coq. foss. des Env. de Paris, tom. ii. pl. 5. f. $34-36$ ).

Sutton.

9. - concinna, Wood (Illust. pl. 7. f. 7).

Sutton.

10. - acuminata? Brug. (B. acuminata, Phil. En. Moll. Sic. t. 7. f. 18. B. acuminata, Grat. Not. sur les Bull. pl. 3. f. 43, 44; not Bulla acuminata, Min. Con.).

Sutton. $|\ldots \ldots \ldots \ldots| \ldots \ldots \mid$ Mediterranean.

This differs from the figures given at the above references in being less slender, and also in being striated more especially at the base, visible in perfect specimens : I am unacquainted with the recent shell. 11. - Lajonkaireana, Bast. (Mém. Géol. de Bord. pl. 1. f. 25. Bulla olivula, Wood, Illust. Mag. Nat. Hist. pl. 7. f. 11. Bulla terebellata, Dubois, de Mont. Foss. de la Wolhyn. pl. 1. f. 8-10).

Sutton. $|\ldots \ldots \ldots \ldots| \ldots \ldots \mid$ Coast of France

This identification is made from the above references: I have not seen the recent shell.

12. - obtusa (Bulla obtusa, Mont. Test. Brit. p. 223. pl. 7. f. 3 , Bulla minuta, Woodward, Geol. of Norf. t. 3. f. 3).

13. - nana, mihi.

| Bramerton. | Britain.

Sutton.

Spec. Char. Shell smooth; volutions four, slightly convex; suture deep ; apex obtuse ; outer lip arcuated, inner slightly replicate ; umbilicus moderate. Axis half a line. Pl. V. f. 1 .

The spire is more elevated and the volutions more rounded than in B. hyalina, to which it approaches nearest.

Many species of this genus are, in the recent state, beautifully transparent; probably it was so with some of these: they are now opake.

\section{Ord. Pneumonobranchiata. \\ Cor. Crag. Red Crag. Mam. Crag. Recent.}

1. Helix hispida, Gray (Edit. of Turt. Man. p. 154. pl. 4. f. 41).

| I Bulcham. I Britain.

2. - pulchella, Gray (Edit. of Turt. Man. p. 154. pl. 5. f. 40).

Bawdsey. | ....... | Britain.

Only one specimen found in loose crag; it has the ferruginous tinge common to the shells of that bed, but for the present must be considered doubtful.

1. Succinea oblonga, Gray (Edit. of Turt. Man. p. 154. pl. 6. f. 39).

Capt. Alexander's cabinet.

Bulcham. | Britain.

1. Conovulus pyramidalis (Auricula pyramidalis, Sow. Min. Con. t. 379$)$.

$\mid$ Sutton. $\left|\begin{array}{c}\text { Thorpe, near } \\ \text { Aldbro.' }\end{array}\right|$


Cor. Crag. Red Crag. Mam. Crag. Recent.

2. Conovulus myosotis (Auricula myosotis, Drap. pl. 3. f. 16, 17).

Sutton. I Bramerton. | France.

Only three specimens from the red crag: Capt. Alexander has found it in the mammaliferous crag near Southwold.

1. Lymnæus palustris, Gray (Edit. of Turt. Man. p. 239.t. 7.f. 107).

| Bulcham. I Britain.

2. - pereger, Gray (Edit. of Turt.Man.p. 233. t. 7.f. 101).

1. Planorbis corneus, Gray (Edit. of Turt. Man. p. 258. pl. 8. f. 95).

I I Bulcham. I Britain.

2. - vortex, Gray (Edit. of Turt. Man. p. 258. pl. 8. f. 91). | | Bulcham. | Britain.

3. - marginatus, Gray (Edit. of Turt.Man. p. 258. pl. 8. f. 88).

1 Butley. I ........ ; Britain.

This is the only genuine freshwater shell that $I$ have seen from either the red or cor. crag. I have but one specimen, procured from undisturbed crag five feet below the bottom of the incumbent sand.

Pl.V. f. 12. is an enlarged representation of a very minute sinistral shell, not more than $\frac{1}{4}$ th part of a line in diameter, somewhat resembling in outline Planorbis corneus, but too small to be the fry, I think, of that species; moreover it has the appearance of a spire more elevated and a deeper umbilicus than in any species of that genus that I am acquainted with, and is probably a marine shell. Three other specimens of about the same size were in my cabinet six years ago, but are now unfortunately lost.

1. Infundibulum rotundum (Patella rotunda, List. Patella Sinensis, Mont. Test. Brit. p. 489. t. 13. f. 4. Infundibulum rectum, Min. Con. t. 97. Infundibulum clypeum, Woodward, Geol. of Norf. t. 3. f. 2).

Sutton. I Sutton. | Bramerton. | Britain. var. $\beta$. depressa.

Sutton. I Sutton.

var. $\gamma$. spinosa*.

2. - subsquamosum, n.s.

|. Walton Naze. |

Ramsholt.

[To be continued.]

L.-Catalogue of the Marine Zoophytes of the neighbourhood of Aberdeen. By John Macgillivray, Esq.

The increasing importance attáched by naturalists to the class of Zoophytes may seem to justify any attempt, however humble, tending to elucidate their local distribution. I feel, therefore, encouraged to submit to the readers of this Journal

\footnotetext{
* One ruw of imbricated spines.
} 


\section{$2 \mathrm{BHL}$ Biodiversity Heritage Library}

Wood, Searles V. 1842. "XLIX.-A Catalogue of Shells from the Crag." The Annals and magazine of natural history; zoology, botany, and geology 9, 455-462. https://doi.org/10.1080/03745484209445364.

View This Item Online: https://www.biodiversitylibrary.org/item/19543

DOI: https://doi.org/10.1080/03745484209445364

Permalink: https://www.biodiversitylibrary.org/partpdf/8849

\section{Holding Institution}

Natural History Museum Library, London

\section{Sponsored by}

Natural History Museum Library, London

\section{Copyright \& Reuse}

Copyright Status: Public domain. The BHL considers that this work is no longer under copyright protection.

This document was created from content at the Biodiversity Heritage Library, the world's largest open access digital library for biodiversity literature and archives. Visit BHL at https://www.biodiversitylibrary.org. 